\title{
Observed changes and variability of atmospheric parameters in the Baltic Sea region during the last 200 years
}

\author{
A. Rutgersson ${ }^{1, *}$, J. Jaagus ${ }^{2}$, F. Schenk ${ }^{3,4}$, M. Stendel ${ }^{5}$ \\ ${ }^{1}$ Department of Earth Sciences, Uppsala University, 75267 Uppsala, Sweden \\ ${ }^{2}$ Department of Geography, University of Tartu, 51014 Tartu, Estonia \\ ${ }^{3}$ Institute for Coastal Research, Helmholtz-Zentrum Geesthacht, 21502 Geesthacht, Germany \\ ${ }^{4}$ Department of Mechanics, KTH Royal Institute of Technology, 10044 Stockholm, Sweden \\ ${ }^{5}$ Danish Climate Centre, Danish Meteorological Institute, 2100 Copenhagen, Denmark
}

\begin{abstract}
The Baltic Sea is located in Northern Europe and exhibits significant climate variability, with influence of air masses from arctic to subtropical origin. By updating and discussing results described in the framework of the BACC project (BALTEX Assessment of Climate Change for the Baltic Sea Basin), this study presents observed changes in atmospheric parameters during the last $200 \mathrm{yr}$. Circulation patterns show large decadal variability with a northward shift of storm tracks and increased cyclonic activity in recent decades with increased persistence of weather types. However, the wind climate shows no robust long-term trends, and is dominated by pronounced (multi-)decadal variability. Near-surface temperatures show continued warming, in particular during spring and winter; this is stronger over northern regions. Up to this point, no long-term trends are detectable for precipitation, although some regional indications exist for an increased length of precipitation periods, and possibly an increased risk of extreme precipitation events.
\end{abstract}

KEY WORDS: Climate change $\cdot$ Climate variability $\cdot$ Baltic Sea region $\cdot$ Observations $\cdot$ Historical climate

\section{INTRODUCTION}

The Baltic Sea is a brackish, semi-enclosed sea located between central and Northern Europe $\left(53^{\circ}-\right.$ $66^{\circ} \mathrm{N}$ and $10^{\circ}-30^{\circ} \mathrm{E}$ ). The drainage basin is roughly 4 times the surface area of the sea with land use ranging from densely populated agricultural areas in the south to sparsely populated forested regions in the north. Situated in the extratropics of the Northern Hemisphere, the Baltic Sea region can be under the influence of air masses from arctic to subtropical origin. It is therefore a region of very variable weather conditions and far reaching teleconnections. The region is dominated mainly by 2 large-scale pressure systems over the northeastern Atlantic, the Icelandic Low and the Azores High, and a thermally driven pressure system over Eurasia (high pressure in winter, low pressure in summer). In general, there are westerly winds over the region, although any other wind direction is also observed frequently. The zonal pressure gradient over the North Atlantic and the position of the Icelandic Low and Azores High mainly influence variations of atmospheric parameters like wind, temperature and humidity in the region. The climate of the Baltic Sea shows a strong seasonal cycle, but also large inter-annual to multidecadal variability. It is important to understand and describe potential long-term changes and variability of atmospheric parameters, as they have large impacts on hydrological, oceanographic and biogeochemical processes in the region. The mostly shallow and complex bathymetry of the semi-enclosed Baltic 
Sea makes the ecosystem very sensitive to any atmospheric changes. Here, the precipitation and temperature control the river runoff to the Baltic Sea with a well-known relation between atmospheric circulation patterns and sea-level, sea-ice, salinity and oxygen. The storm frequency clearly influences Baltic Sea mixing and marine ecosystems.

Here we present an updated summary of existing data and previous investigations done within the framework of the BACC (BALTEX Assessment of Climate Change for the Baltic Sea Basin) projects (BACC Author Team 2008, 2014). The data is extended to also cover 2013, as well as a brief analysis of the blocking feature and impact of Arctic ice reduction. We focus on the last $200 \mathrm{yr}$ to rely on robust in situ measurements only. The Baltic Sea area is relatively unique in terms of long-term data, with a dense observational network covering an extended time period, although many national (sub-) daily observations still await digitization and homogenization.

A network of stations with continuous and relatively accurate measurements has been developed since the middle of the 19th century (few stations were established in the middle of the 18th century). Satellites were introduced in 1978, which significantly improved data coverage, providing higher resolution in space and time. Data that spans extended periods cannot be expected to be homogeneous in time. It is therefore important that conclusions concerning long-term trends are drawn from homogenized data. Also gridded data sets cannot be expected to be homogeneous as the density and quality of the assimilated data undergoes spatial and temporal changes. Temperature measurements cover relatively extended periods, and significant efforts have been made to homogenize station data and databases. It can thus be expected that trends in temperature are relatively robust, even though uncertainties are larger for earlier data (e.g. Brohan et al. 2006). Direct wind observations cover usually relatively short periods and suffer from strong inhomogeneities (e.g. WASA 1998), so that most studies rely on reanalysis data or on reconstructions based on pressure observations (see Feser et al. 2014 for a review). So far, pressure based reconstructions might yield more robust long-term trend analysis than reconstructions based on longterm reanalysis products over the Euro-Atlantic region since 1871 (Krueger et al. 2013, Dangendorf et al. 2014). The highly variable nature of precipitation with large local to regional differences together with the limited availability of data makes homogenisation of this quantity difficult.
It is during the latter part of the investigated period that the potential recent anthropogenic influence could be seen. As little long-term observations are available for many variables, it remains difficult to interpret recent changes in the context of the last 200 yr. The focus is here on physical parameters characterizing the atmosphere, like circulation patterns, wind, temperature, and precipitation, where reliable data allows such an analysis.

\section{LARGE-SCALE CIRCULATION PATTERNS}

The atmospheric circulation in the European/ Atlantic sector plays an important role for the regional climate of the Baltic Sea basin (Hurrell 1995, Slonosky et al. 2000, 2001, Moberg \& Jones 2005, Achberger et al. 2007). It can be described mainly by the North Atlantic Oscillation (NAO), the zonality of the atmospheric flow and the blocking frequency. The first mode of a principal component analysis (PCA) of winter sea-level pressure (SLP) variability is the NAO, which in winter shares a close correlation with atmospheric and marine state variables of the Baltic Sea region (where a positive index indicates mild and wet winters and a negative index indicates cold and dry winters). Fig. 1 shows the winter NAO index for 1823 to 2013. In a long term perspective, the behavior of the NAO is rather irregular. However, for the last 5 decades, specific periods are apparent. Beginning in the mid-1960s, a positive trend has been observed, i.e. toward more zonal circulation with mild and wet winters and increased storminess in central and northern Europe, including the Baltic Sea area (e.g. Hurrell et al. 2003). After the mid1990s, however, there was a tendency towards more negative NAO indices, in other words, a more meridional circulation. The strongly positive NAO phase in the 1990s can be seen as part of a multi-decadal variation comparable to that at the beginning of the 20th century rather than a trend towards more positive values (Jones et al. 1997, Slonosky et al. 2000, 2001, Moberg et al. 2005).

The second mode of the PCA is called the East Atlantic pattern (Wallace \& Gutzler 1981) and represents changes in the north-south location of the NAO (Woollings et al. 2008). It is characterized by an anomaly in the northeastern North Atlantic, between the NAO centers of action. Negative values mean a southward displacement of the NAO centers of action and lower temperatures (Moore \& Renfrew 2011); positive values correspond to more zonal winds over Europe and expected higher tempera- 


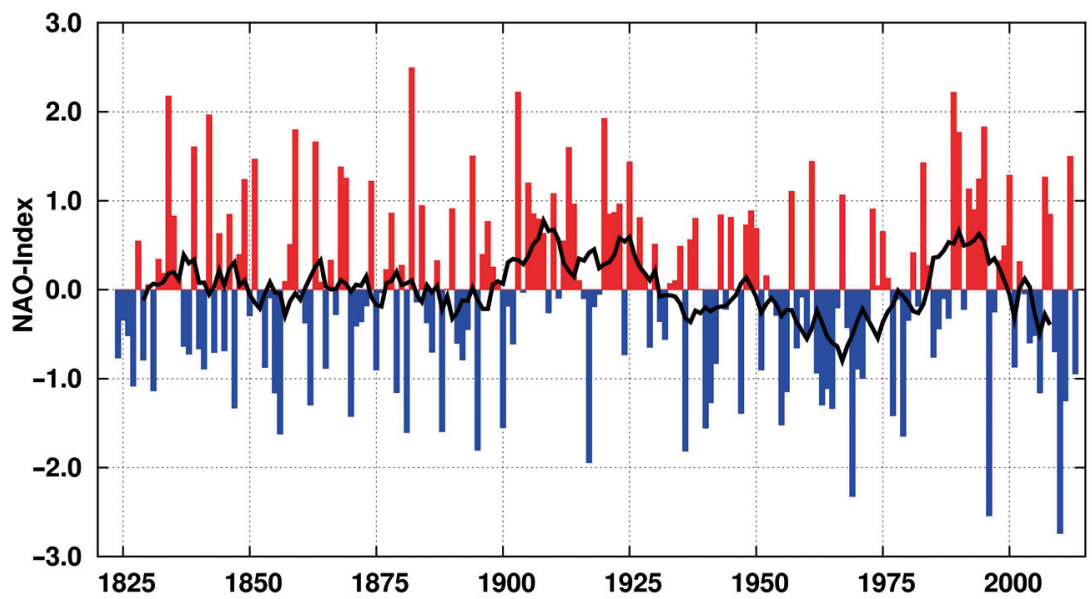

Fig. 1. NAO index for boreal winters (DJFM) of 1823-2013 (Jones et al. 1997). Updated via www.cru.uea.ac.uk/ timo/datapages/naoi.htm and re-normalized for the period 1824-2013. Black line: $11 \mathrm{yr}$ running mean highlights decadal-scale variability. Bars: positive (red) and negative (blue) indices perature (see Fig. 6b) and wind (see Fig. 5) anomalies and annual storminess variations (see Fig. 4) in the Baltic Sea region during the 20th century.

Kyselý \& Huth (2006) show an intensification of zonal circulation in particular during the 1970s and 1980s, followed by intensified cyclonic activity over Fennoscandia along with more frequent blocking situations over the British Isles. While there is a general increase in the zonality of the flow in winter, the opposite takes place in summer (Kaszewski \& Filipiuk 2003, Wang et al. 2009a, 2011). There are also indications (Kyselý 2000, 2002, Werner et al. 2000, Kyselý \& Huth 2006) that weather types are more persistent than in earlier decades. For all weather types (zonal, tures. The third dominant mode is the Scandinavian pattern, also called the Eurasian (Wallace \& Gutzler 1981) or blocking pattern (Hurrell \& Deser 2009), which in its positive phase is characterized by a high pressure anomaly over Scandinavia and a low pressure anomaly over Greenland. This indicates an east-west shift of the northern center of variability defining the NAO. The corresponding negative phase is sometimes referred to as an Atlantic ridge.

Rimbu \& Lohmann (2011) constructed a North Atlantic blocking index which also shows pronounced decadal variations with more frequent blocking in the 1910s, 1940s and 1960s as well as after 1995, and low blocking in particular in the 1920s, 1970s and early 1990s. Fig. 2 shows the blocking frequency for 1948 to 2012 using 3 definitions with some differences in the patterns. Together with the NAO, these large variations in blocking frequency are in very good agreement with the observed mean winter temmeridional, or anticyclonic), an increase in persistence in the order of 2 to $4 \mathrm{~d}$ is found from the 1970 s to the 1990s. This increase in persistence may contribute to an increase in the occurrence of extreme events.

Circulation changes in the Baltic Sea region may also be related to climate anomalies in other regions. Many authors discuss the cold temperatures of the winters 2009-2010 and 2010-2011 over large parts of Europe (including the Baltic Sea region). Overland \& Wang (2010) point out a relationship of circulation changes in the Baltic Sea region to the loss of sea ice in the Arctic. For a reduction in Arctic summer sea ice, additional heat is stored in the Arctic Ocean due to the increase in late summer open water area, and contributes to an increase in the lower tropospheric relative topography (thickness of the layer between 500 and $1000 \mathrm{hPa}$ surfaces). As a consequence, anomalous easterly winds are observed in the lower troposphere along $60^{\circ} \mathrm{N}$ in many regions. Petoukhov
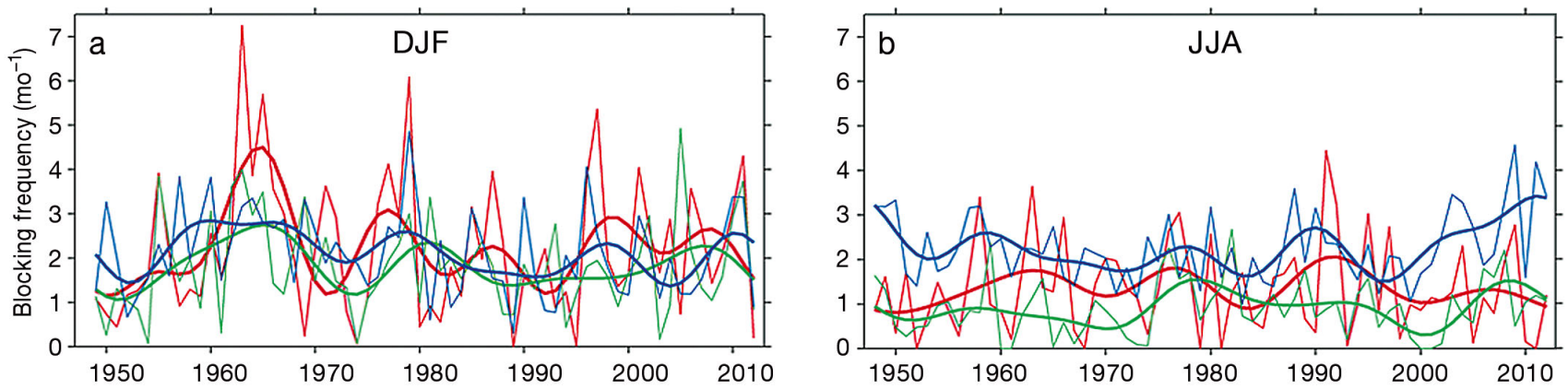

Fig. 2. Mean monthly blocking frequency in boreal (a) winter (DJF) and (b) summer (JJA) blocking over the North Atlantic $\left(40^{\circ}-80^{\circ} \mathrm{N}, 60^{\circ} \mathrm{W}-0^{\circ}\right)$ in the NCEP reanalysis for 1948-2012 using 3 different definitions of blocking as described in Barnes et al. (2014). Thin blue, red and green lines for the 3 different indicies; thick lines: smoothed time series obtained using a Lanczos filter with a cutoff frequency of $10 \mathrm{yr}$ 
\& Semenov (2010) performed a series of experiments with the ECHAM5 model, and found a dependence of central European winter temperatures on sea ice cover in the Barents and Kara (BK) Seas. A gradual decrease in sea ice from $100 \%$ to ice-free conditions leads to a strong temperature increase via a nonlinear relationship between convection over the ice-free parts and baroclinic effects triggered by changes in temperature gradients near the surface heat source. Yang et al. (2011), using the EC-Earth model (Hazeleger et al. 2012) with considerably higher resolution than Petoukhov \& Semenov (2010), confirm a decrease in winter temperatures with decreasing BK sea ice, but in a more linear way than in Petoukhov \& Semenov (2010).

Fig. 3 shows the variation in the August ice edge position (in degrees latitude) in the Barents Sea (Vinje 1998, 2001) and minimum sea ice volume determined using satellite data with the Pan-Arctic IceOcean Modeling and Assimilation System (PIOMAS; Schweiger et al. 2011) and the mean DJF temperature anomaly in the northern part of the Baltic Sea region for the respective periods (see Section 4 for explanation of temperature data). The ice edge shifts northward (Fig. 3a shows a linear trend for the period 1851 to 1999), sea ice volume decreases (Fig. 3b shows a linear trend for the period 1979 to 2011), and the Baltic Sea winter temperature increases (Fig. 3c\&d show linear trends for the respective periods). Table 1 shows the correlation of temperature and ice parameters (ice volume and ice extent respectively). There is no simple correlation between the ice parameters (ice edge or volume) and the DJF temperature. The correlation coefficient of the detrended ice and temperature time series (linear trends shown in Fig. 3 subtracted prior to the correlation) is larger for ice volume and temperature $\left(\mathrm{r}_{\text {detrended }}=0.3\right.$ giving an explained variance of $10 \%$ for the period 1979 to 2012) than for the non-detrended data for 1979 to 2012. The ice data sets are not entirely comparable, as Barents Sea ice edge and total ice volume are only partly related. Thus, by using ice volume observations from the last $30 \mathrm{yr}$, only a weak signal of the reduced ice is seen in the winter temperatures in the Baltic Sea region. For the extended time period and the crude estimate of ice edge in the Barents Sea, no simple correlation with Baltic Sea winter temperatures exists. There is no correlation between the ice extent in the Barents Sea region and the Baltic Sea temperature for the period 1850 to 1998 . However, this does not rule out a more complicated relation. In Yang et al. (2011) it was suggested that different cir-
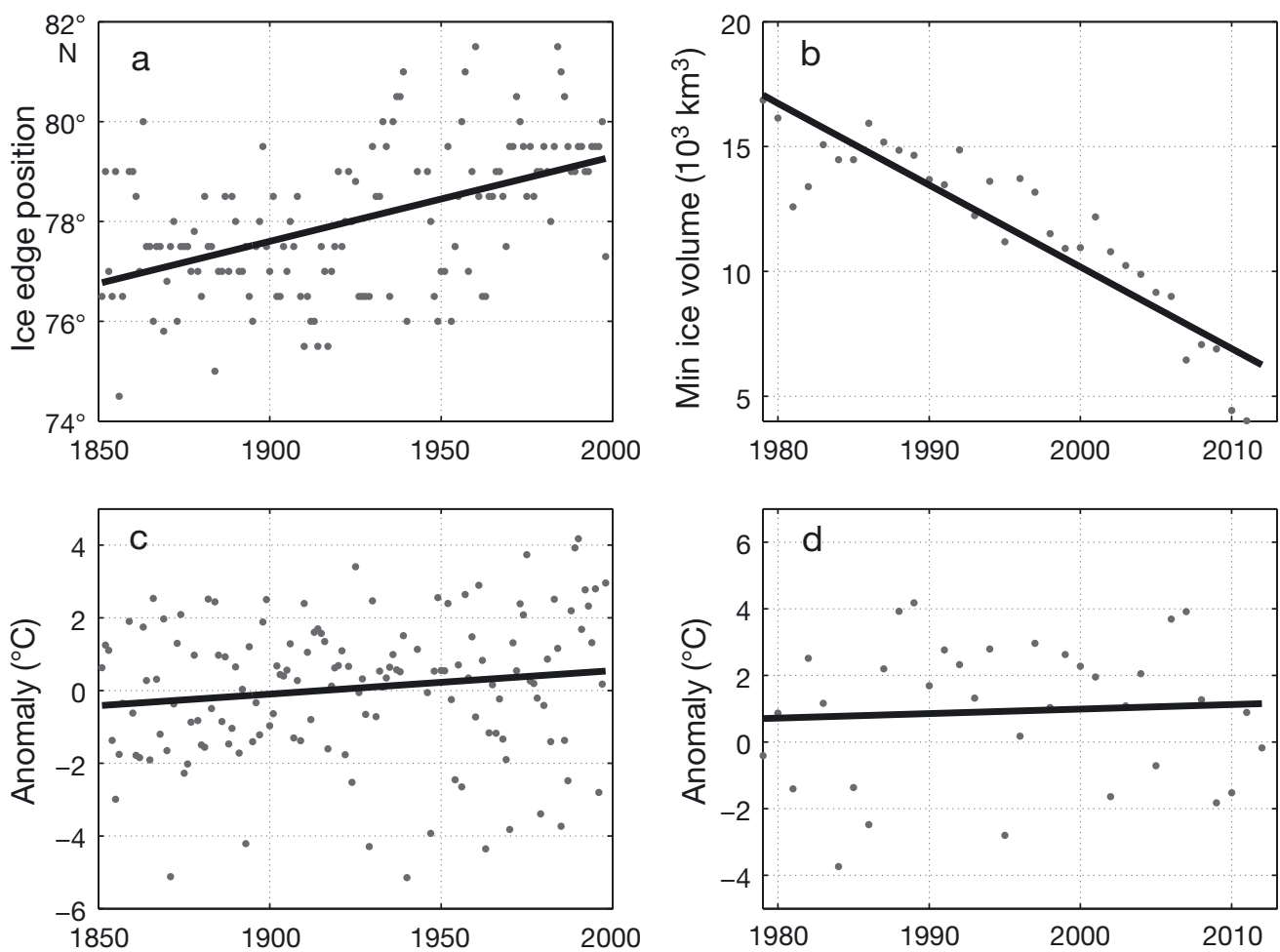

Fig. 3. (a) Position of ice edge during August in the Barents Sea for 1851-1998; (b) Minimum Arctic ice volume for 1979-2012; Temperature anomaly for the winter seasons (DJF) of (c) 1851-1999 and (d) 1979-2013. Annual values (dots) and linear trends (lines) for the respective periods 
Table 1. Correlation coefficients between ice properties and temperature with (r) and without long-term trends ( $\mathrm{r}_{\text {detrended }}$ ) for the northern $\left(>60^{\circ} \mathrm{N}\right)$ and southern $\left(<60^{\circ} \mathrm{N}\right)$ Baltic Sea regions for periods $1850-1998$ and 1979-2012

\begin{tabular}{|lcc|}
\hline Data sets & 1850-1998 & 1979-2012 \\
\hline r(Northern) & -0.03 & -0.08 \\
r(Southern) & 0.13 & 0.07 \\
$\mathrm{r}_{\text {detrended (Northern) }}$ & 0.06 & 0.32 \\
$\mathrm{r}_{\text {detrended (Southern) }}$ & 0.07 & 0.31 \\
\hline
\end{tabular}

culation regimes have different impacts on the relation between Arctic ice and European temperatures.

This finding is corroborated by Barnes et al. (2014) who investigate the connection of Northern Hemisphere blocking and Arctic sea ice retreat. Comparing 4 different reanalysis products and considering 3 different definitions of blocking (Barnes et al. 2012, Dunn-Sigouin et al. 2013, Masato et al. 2013), the authors find no clear evidence for robust trends in blocking frequency or onset. It should, however, be noted that this does not automatically imply that such trends do not exist, since the 4 investigated reanalyses show quite different results, even though they are essentially based on the same raw data. This may further complicate the detection of changes in blocking. In contrast, Francis \& Vavrus (2012), Liu et al. (2012) and Tang et al. (2013) suggest a connection between sea ice retreat and the occurrence of blocking. More research is required to increase our understanding of the impact of declining sea ice on regional boreal climates like the Baltic Sea region.

\section{WIND CLIMATE}

Variations in the wind climate over the Baltic Sea region are on average closely linked to the atmospheric circulation and cyclonic activity over the North Atlantic. Based on NCEP/NCAR reanalysis data over the North Atlantic since 1958, the number of deep cyclones (core pressure $<980 \mathrm{hPa}$ ) in winter (DJFM) reached a minimum in the early 1970s and clearly increased in the following decades, reaching their maximum around the last decade of the 20th century (Lehmann et al. 2011). At the same time, a continuous shift of North Atlantic storm tracks towards the north-east regionally increased the impact and number of storms over Northern Europe in winter and spring of recent decades, but decreased in autumn. Following the intensification of deep lows, a significant positive trend exists for storminess since the middle of the last century in reanalysis data over this region (Donat et al. 2011).

On a larger spatial scale, the pattern of increasing storm activity and wave heights over the northern North Atlantic, decreasing trends in lower midlatitudes, and NE shift of storm tracks in boreal winter for 1955-2004 appears to be consistent with a combined influence of anthropogenic and natural forcing, while it is less likely that external forcing played an important role in the first half of the 20th century (Wang et al. 2009b). While the spatial trend pattern of the last 40 to $60 \mathrm{yr}$ is consistent with scenario simulations of the 21st century under increased greenhouse gas concentrations (e.g. Ulbrich et al. 2009, Feser et al. 2014), the question about potential long-term trends in storminess is currently disputed, as no homogeneous wind observations are available on longer timescales.

As synoptic-scale storms are generally linked to the large-scale forcing over the pressure field, one possibility is to use pressure gradients to derive geostrophic wind speeds from triplets of surface pressure readings (Krueger \& von Storch 2011). Based on high annual percentiles of geostrophic wind speeds calculated from a triangle of station pressure over the German Bight, Schmidt \& von Storch (1993) did not find any long-term trend for the wind climate of 1876-1990. The absence of robust long-term trends was confirmed by numerous storm indices over the NE-Atlantic, North Sea, southern Baltic Sea region and central Europe (e.g. Alexandersson et al. 2000, Matulla et al. 2008, Bärring \& Fortuniak 2009, Wang et al. 2009a) showing similar high storm levels during the 1880s as observed in the 1990s with a distinct minimum in the 1970s (see Feser et al. 2014 for a review).

While the previous storm indices present local to regional wind statistics, 2 novel datasets became available recently which try to construct physically consistent atmospheric fields on longer timescales. (1) By assimilating surface pressure records into a state-of-the-art global climate model, the 20th Century Reanalysis (20CRv2; Compo et al. 2011) suggests significant positive trends for storminess since 1871 over the Euro-Atlantic and to a less extent over the Baltic Sea region (Donat et al. 2011). The obviously inconsistent long-term trends relative to observations seem to be related to 20CRv2 assimilating fewer pressure observations back in time, which leads to spurious upward trends in 20CRv2 before 1940 over the NE-Atlantic (Krueger et al. 2013) and before 1910 over the North Sea region (Dangendorf et al. 2014). The latter study confirms results from 
pressure-based storm indices showing no long-term trend since 1843, by using independent data of storm surges at Cuxhaven on the German North Sea coast. If the surges are derived through statistical regression using 20CRv2 as predictor, the comparison with the observed record suggests that 20CRv2 is locally consistent only after around 1910. To which extent 20CRv2 consistent over the Baltic Sea region needs to be further evaluated.

(2) Schenk \& Zorita (2012) recently released a new reconstruction of HIgh RESolution Atmospheric Forcing Fields (HiResAFF) for Northern Europe that was extended for the period 1850-2009 (Gustafsson et al. 2012). Based on the pattern similarity between daily SLP station data in the past with SLP observations since 1958, historical atmospheric fields were reconstructed by taking the daily atmospheric fields of regionally downscaled ERA40 reanalysis for any day in the past for which the pattern similarity is maximized for an analogous day in the 1958-2007 period (Schenk \& Zorita 2012). As shown in Fig. 4, the reconstructed 99th percentile of annual wind speeds from HiResAFF in the vicinity of Stockholm yield comparable results regarding long-term features of annual storminess derived from single-station proxies of Stockholm used by Bärring \& Fortuniak (2009). Divergence of storm indices before 1850 (Fig. 4) are caused by non-regular observation times on a sub-daily scale where daily quantities (green line) provide a more robust measure.

While the previous studies analysed historical storminess on an annual basis, Wang et al. (2009a) repeated and updated (1874-2007) previous studies based on the 99th percentiles of geostrophic wind speed over the NE Atlantic, Northern and Central Europe, and focused more on seasonal and regional differences. They found that the maxima in the 1990s are due to winter storminess, while the high annual storm values in the 1880 s are mainly due to summer storminess. For the period 1878-2007, Wang et al. (2011) found weak negative trends in the 99th percentiles over central Sweden and the southwestern Baltic Sea in winter (DJF) and a clear $(p<0.05)$ negative trend over the southwestern Baltic Sea in summer (JJA). As shown in Fig. 5, HiResAFF (Schenk \& Zorita 2012) confirms decreasing seasonal mean wind speeds in summer as in Wang et al. (2011) and the peak in summer wind speeds in the 1880s (Wang et al. 2009a), i.e. over the western Baltic Sea region. According to HiResAFF, the peak in summer winds extends still further back in time to the 1850s. However, no increased summer windiness is reconstructed in the 1880s over the Northern and Eastern
Baltic Sea, highlighting regional differences in the wind climate. While Wang et al. (2009a) attribute high annual storminess in the 1880s mainly to higher storminess in summer, HiResAFF shows higher mean wind speeds in all seasons except autumn over the western and central Baltic Sea in the 1880s.

The current knowledge about the long-term evolution of the wind and storm climate is far from complete, both on a regional scale and regarding extreme cyclone developments like the one in January 2007 (Fink et al. 2009). This implies that a detailed analysis of extreme cyclones on a synoptical scale is limited to the last decades, with little direct information on longer timescales. Station pressurebased reconstructions of long-term wind and storm statistics indicate quasi-stationary conditions with prominent (multi-) decadal variations (Feser et al. 2014). These results are consistent with externally forced Atmosphere-Ocean General Circulation Models for the last millennium (e.g. Fischer-Bruns et al. 2005, Xia et al. 2013) showing no response in Northern Hemispheric storm characteristics related to changes in external forcing. Only under strongly increasing greenhouse gas (GHG) conditions is a NE shift of storm tracks proposed over the North Atlantic (Fischer-Bruns et al. 2005, Ulbrich et al. 2009). It remains open if the currently observed NE shift of storm tracks since the 1960s (Lehmann et al. 2011) is a harbinger of already increased GHG concentrations, as suggested by Wang et al. (2009b), based on the period since 1900, because the conditions around the 1880s appear to be similar to the 1990s regarding the magnitude and frequency of storm activity.

\section{SURFACE AIR TEMPERATURE}

Earlier studies have detected quite a significant surface air temperature increase in the Baltic Sea region during 1871-2004 (BACC Author Team 2008). The warming has partly continued up to the present (during summer in the southern parts and during autumn in the north), although some winters during the last decade have been relatively cold (Fig. 6).

The temperature increase is not monotonous but accompanied by large (multi-) decadal variations dividing the 20th century into 3 main phases: (1) warming in the beginning of the century until the 1930s; (2) cooling until 1960s; and (3) another distinct warming during the last decades of the time series. Linear trends of the annual mean temperature anomalies during 1871-2013 were $0.10 \mathrm{~K}$ decade ${ }^{-1}$ north of $60^{\circ} \mathrm{N}$ and $0.08 \mathrm{~K}_{\text {decade }}{ }^{-1}$ south of $60^{\circ} \mathrm{N}$ in the Baltic 

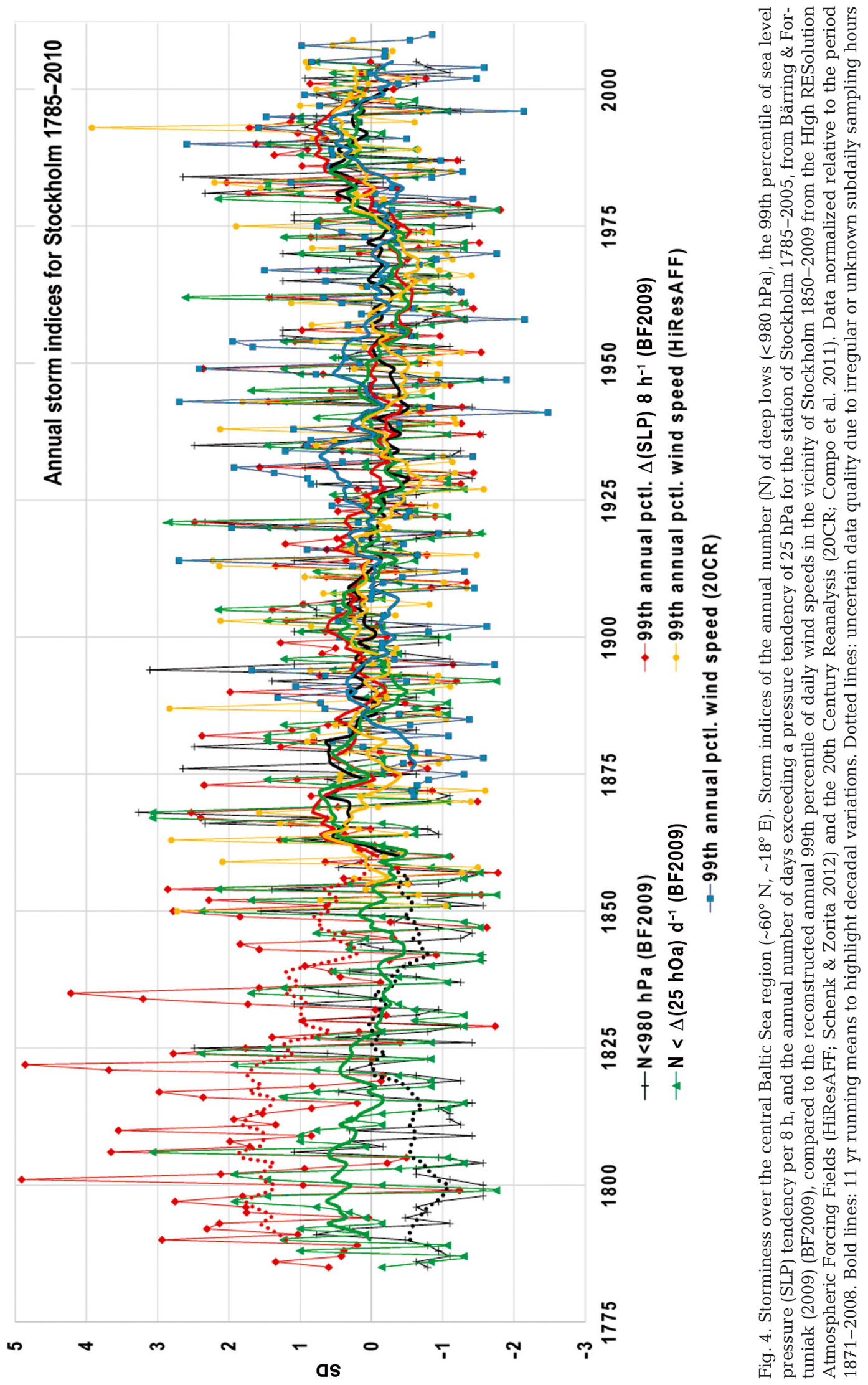


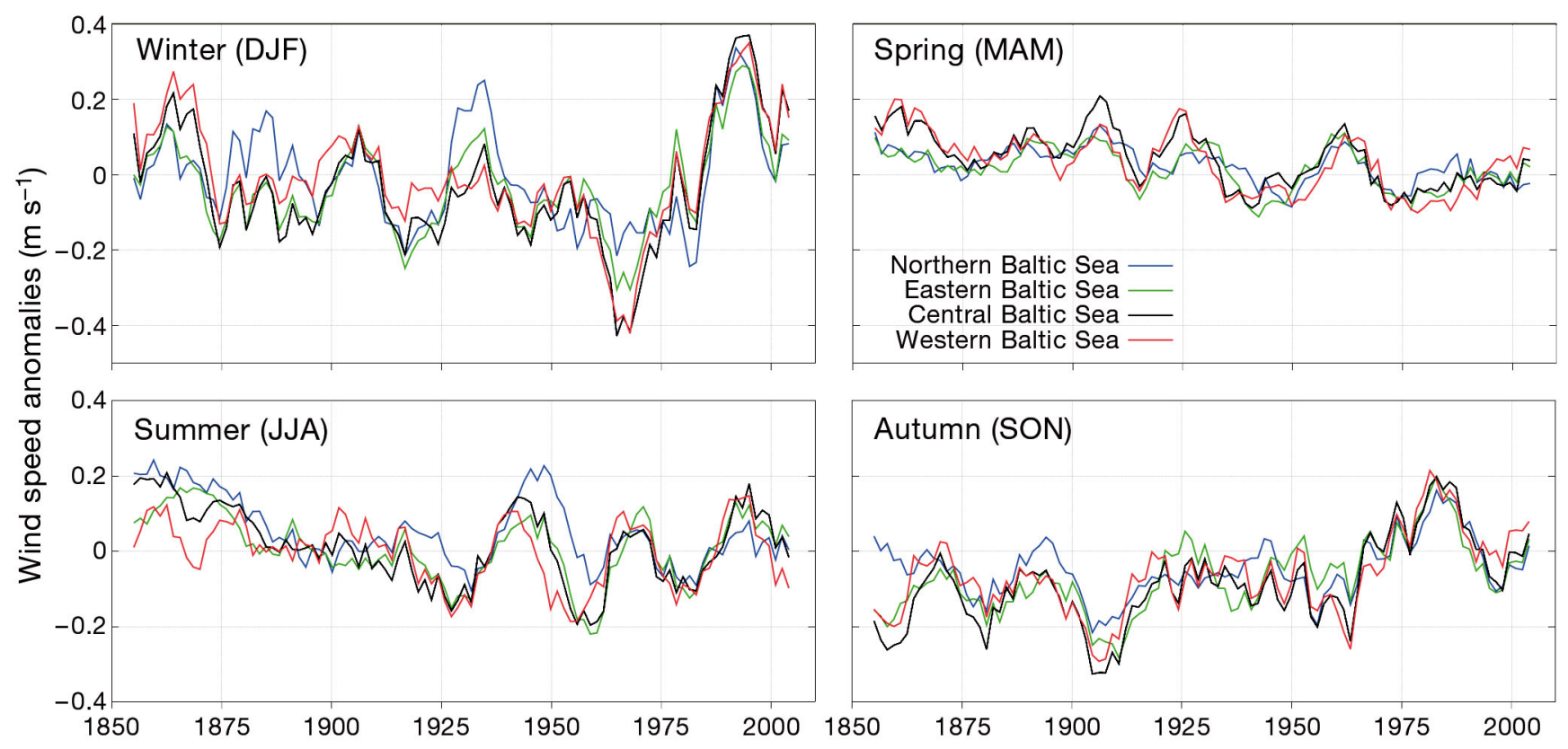

Fig. 5. Sliding decadal (11 yr) mean seasonal wind speed anomalies for the Baltic Sea regions for 1850-2009 relative to the mean of 1958-2007. Time series are drawn from the gridded fields of HIgh RESolution Atmospheric Forcing Fields (HiResAFF; Schenk \& Zorita 2012). Grid points are selected in the closest vicinity of Haparanda, Saint Petersburg, Helsinki, Stockholm, Kaliningrad and Copenhagen

Sea region (Table 2). This is larger than the global mean temperature trend, which is about $0.06 \mathrm{~K}$ decade $^{-1}$ for the period 1871-2005 (IPCC 2007). All seasonal trends are positive and significant at the $95 \%$ level, except winter temperature north of $60^{\circ} \mathrm{N}$ (because of the large variability). The largest trends are observed in spring and the smallest in summer, with higher seasonal trends in the northern area compared to the south. The annual and seasonal time series of surface mean air temperature for the Baltic Sea basin, separately for its northern and southern parts, are shown in Fig. 6, sharing more or less similar variations and trends to those of the European mean air temperature (Casty et al. 2007).

For the more recent decades, an analysis of temperature trends from 1970 to 2008 in the Baltic Sea area showed the strongest increase in the Gulf of Bothnia in autumn and winter $\left(0.5\right.$ to $\left.0.6 \mathrm{~K} \mathrm{decade}^{-1}\right)$, while significant changes occurred during spring and summer in the central and southern parts of the Baltic Sea area (an increase of 0.2 to $0.3 \mathrm{~K} \mathrm{decade}^{-1}$ ) (Lehmann et al. 2011). Large temperature changes over the northern Baltic Sea in winter and spring are very likely related to a reduction of ice seen during the same period (BACC Author Team 2014).

Results of studies on regional temperature changes agree with these general results. The increase in annual mean air temperature for Finland during
1909-2008 was $0.09 \mathrm{~K}$ decade ${ }^{-1}$ (Tietäväinen et al. 2010). In the southeastern part of Norway it was $0.07 \mathrm{~K} \mathrm{decade}^{-1}$ for the same period. The trend value $0.09 \mathrm{~K}$ decade ${ }^{-1}$ was found for Riga, Latvia, in the period 1851-2006 (Lizuma et al. 2007). During the second half of the 20th century, the trend values were much larger: approximately $0.3 \mathrm{~K} \mathrm{decade}^{-1}$ for annual mean temperature was observed in Estonia in 1950-2009 (Russak 2009, Kont et al. 2011). Temperature fluctuations have been coherent in all 3 Baltic states (Kriauciuniene et al. 2012).

The daily temperature cycle is also changing, with both the mean minimum and mean maximum temperature in the Baltic Sea area increasing over the past century. The mean maximum temperature has increased more rapidly in the latter part of spring (April and May), while the mean minimum temperature has increased more than the maximum temperature in much of the winter (BACC Author Team 2008, Avotniece et al. 2010, Jaagus et al. 2013). Consequently, the diurnal temperature range has increased in spring and decreased in winter. No changes in the annual mean diurnal temperature range were detected in the Baltic countries (Jaagus et al. 2013).

In addition to an increase in mean temperatures, there has been an increase in temperature extremes. For example, in Poland a statistically significant increase in the annual number of days with daily max- 


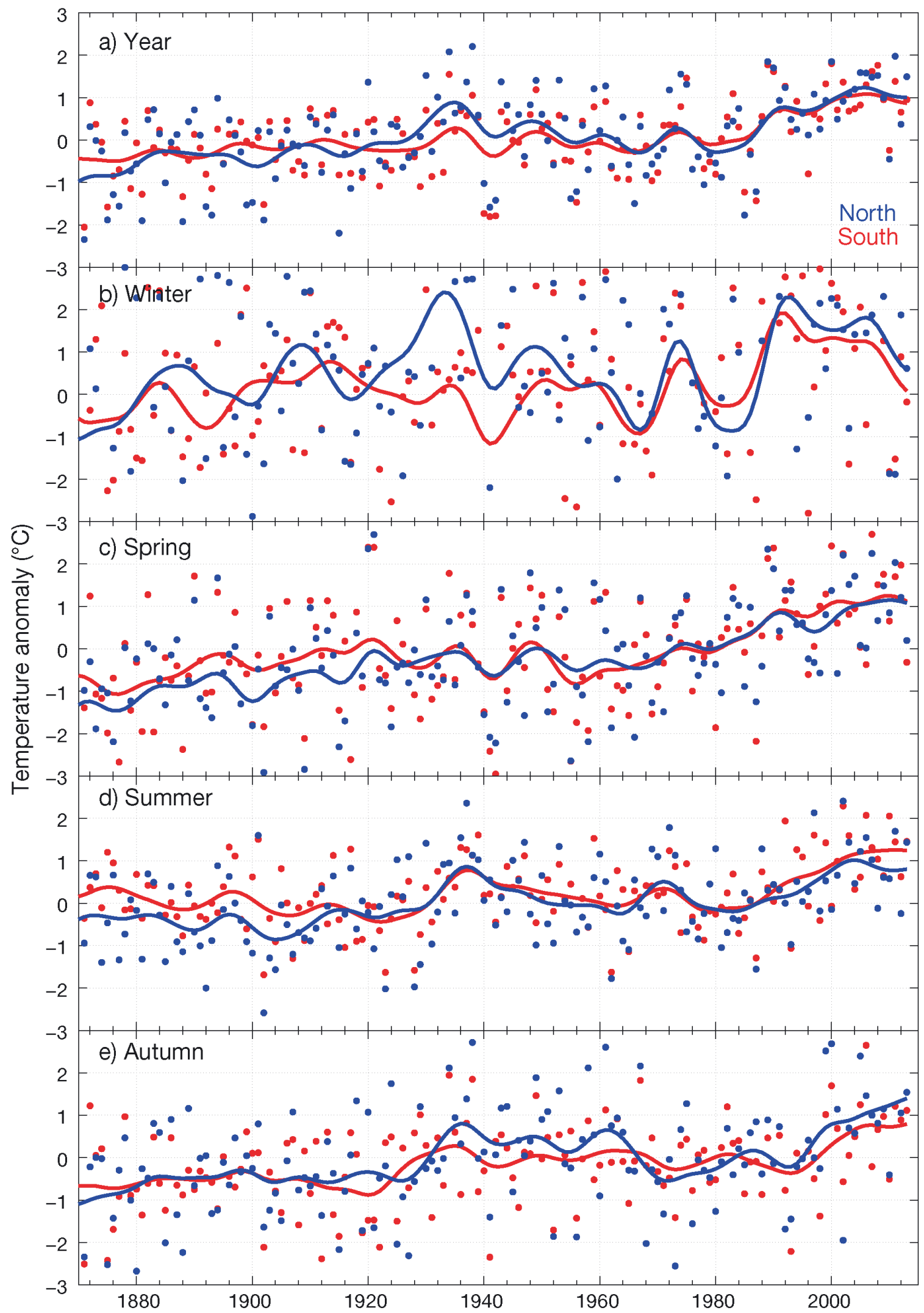

Fig. 6. Annual and seasonal mean near-surface air temperature anomalies for the Baltic Sea Basin for 1871-2013, taken from the CRUTEM3v dataset (Brohan et al. 2006). Blue, red: Baltic Sea basin region north and south, respectively, of $60^{\circ}$ N. Dots: individual years. Smoothed curves: variability on timescales longer than $10 \mathrm{yr}$ 
Table 2. Linear surface air temperature trends $\left(\mathrm{K} \mathrm{decade}^{-1}\right.$ ) for the period 1871-2013 over the northern $\left(>60^{\circ} \mathrm{N}\right)$ and southern $\left(<60^{\circ} \mathrm{N}\right)$ Baltic Sea basin. Bold: significance at $\mathrm{p}<$ 0.05. Data from the updated CRUTEM3v dataset (Brohan et al. 2006)

\begin{tabular}{|c|c|c|c|c|c|}
\hline & Annual & Winter & Spring & Summer & Autumn \\
\hline Northern area & 0.10 & 0.08 & 0.14 & 0.08 & 0.10 \\
\hline Southern area & 0.08 & 0.09 & 0.11 & 0.05 & 0.08 \\
\hline
\end{tabular}

imum temperature above $25^{\circ} \mathrm{C}$ (also the number of days with maximum temperature above $30^{\circ} \mathrm{C}$ ) was observed for the period 1951-2006 (Wibig 2008), while a significant decrease was observed in the length of the frost season and in the annual number of frost days (daily minimum below $0^{\circ} \mathrm{C}$ ) and ice days (daily maximum below $0^{\circ} \mathrm{C}$ ). Furthermore, the duration of extremely mild periods increased significantly in winter, and the number of heat waves increased in summer (Scaife et al. 2008, Wibig 2008, Kysely 2010).

These changes are also resulting in seasonality changes: the length of the growing season has increased, whereas the length of the cold season has decreased. The number of days by which autumn and winter are delayed differs from south to north and east to west, but as an example in Tartu, Estonia, the number of deep winter days (with snow cover) has decreased by $29 \mathrm{~d}$ over the past century while the growing season has increased by $13 \mathrm{~d}$ in this period (Kull et al. 2008).

\section{PRECIPITATION}

The amount of precipitation in the Baltic Sea area during the past century has varied between regions and seasons, with both increasing and decreasing precipitation and no general trend during the period 1766-2000 (Casty et al. 2007). A tendency of increasing precipitation in winter and spring was detected during the second half of the 20th century (Zolina et al. 2009). Comparing downscaled and modelled precipitation from 27 stations in Fennoscandia during 1957-1999, a trend analysis was performed (Benestad et al. 2007) which found only few locations exhibiting trends that were statistically significant at the $5 \%$ level.

Trends in precipitation in particular countries depend very much on time frames, seasons and locations. An increase in precipitation was detected in southeastern Norway (Hanssen-Bauer et al. 2009). Annual precipitation has increased about 15 to $20 \%$ during 1900-2010, which has been higher in autumn and winter, and lower in spring and summer. Summer precipitation in Finland during 1908-2008 shows a positive trend (Ylhäisi et al. 2010). Statistically significant trends in south-western Finland were detected in June and in northeastern Finland in May, July and for the whole summer period (MJJAS). There were no clearly expressed trends in Latvia during the longer period 1922-2003 (Briede \& Lizuma 2007). During the last decades a statistically significant increasing trend was detected in southeastern Norway (Hanssen-Bauer et al. 2009), Lithuania, eastern Latvia and eastern Estonia (Jaagus et al. 2010). Comparing annual mean precipitation during 1994-2008 with that of 1979-1993, less precipitation was observed in the northern and central Baltic Sea, and more precipitation in southern region (Lehmann et al. 2011).

The increase in precipitation in Northern Europe is also associated with an increase in the frequency and intensity of extreme precipitation events; the number of extreme precipitation days per year and the seasons in which they occur vary for the different catchment areas of the Baltic Sea. Wet periods with daily precipitation exceeding $1 \mathrm{~mm}$ have become longer over most of Europe by about 15 to $20 \%$ during 1950-2008 (Zolina et al. 2010). The lengthening of wet periods was not caused by an increase of the total number of wet days. Becoming longer, wet periods in Europe are now characterized by an increase in heavy precipitation. Heavy precipitation events during the last 2 decades have become much more frequently associated with longer wet spells and have intensified in comparison with the 1950s and 1960s (Zolina 2011).

The number of days with precipitation exceeding given thresholds, lengths of wet and dry spells, and precipitation amounts in single spells were analysed using daily data from 5 stations in Poland during the second half of the 20th century (Wibig 2009). A positive trend was detected for the number of wet spells and days with precipitation, while a negative trend was found for mean precipitation during a given spell. Positive as well as negative trends in indices of precipitation extremes were detected in Poland for 1951-2006, but the highest number of decreasing trends was in summer, especially in southern Poland, whereas the number of increasing trends was more pronounced in spring and autumn (Łupikasza 2010). The number of heavy precipitation events has increased in all Baltic states: Lithuania, 1951-2006 (Rimkus et al. 2011); Latvia, 1924-2008 (Avotniece et al. 2010); and Estonia, 1957-2009 (Tammets \& Jaagus 2013). 


\section{OPEN QUESTIONS}

There are a number of open questions related to changes in atmospheric parameters during the last $200 \mathrm{yr}$, for which continued research is required to understand and describe climate change/variability. Of particular interest are the distant controls of circulation changes. Is there a relation between reduced ice in the Arctic and low winter temperatures in the northern European regions, as suggested by Overland \& Wang (2010)? As the reduction of Arctic sea ice seems to continue, a potential effect on circulation patterns over the Baltic Sea region would be of crucial importance for Baltic Sea climate. Although the global warming signal is clearly reflected in mean temperature change, altered circulation patterns would most likely have a larger impact on several state variables.

Although Bhend \& von Storch (2009) detected a clear long-term temperature change over the Baltic Sea region, the separation of natural and anthropogenic signals requires more research. As an example, the Atlantic Multidecadal Oscillation (AMO) originates in the Atlantic and is defined from patterns in the SST variability. Several studies have shown that AMO can force European climate (e.g. Rodwell et al. 1999, Kushnir et al. 2002, Sutton \& Hodson 2005, Semenov et al. 2010). These signals may superimpose long-term trends and be an indication of the impact of the ocean on the European climate on a multidecadal scale. Such variations are likely associated with natural rather than anthropogenically forced variability (Gulev et al. 2013). The relation to climate variability in the Baltic Sea region is, however, not clear.

Persistence of circulation types has increased during the last century and might be also related to the reduction of Arctic ice. The persistence of weather types can explain the increase in frequency and intensity of extreme precipitation events. For extreme events however, current studies rely on a rather small amount of data covering usually relatively short time scales, and it is difficult to draw any statistically significant conclusions. For reliable trend estimates there is a need for more homogenised, unbiased data. This is particularly important when evaluating trends of rarely occurring extreme events with large local differences.

As the anthropogenic GHG emissions are most significant during the last decades, human induced climate change signals should dominate during this period. The Baltic Sea (as a semi-enclosed sea basin) could be considered as a modulator for global climate change signals, but the region can also generate its own signals. On the regional level, the discrimination of anthropogenic and natural signals, and the differentiation between locally forced changes and globally imposed ones still remain an open question. The Baltic Sea region has relatively unique long-term data, and there is strong motivation for further research in this region (Meier et al. 2014).

The past $200 \mathrm{yr}$ have the advantage of in situ measurements with relatively high accuracy. We would, however, like to point out the need for extension of long-term reanalyses and the homogenisation of such products. The long-term temperature and, to some extent, wind trends, are relatively reliable, but long term trends using existing data of precipitation and extreme events are significantly less reliable. There is a need for an extension and a homogenisation of existing reanalysis products (like 20CR and ERA) which would be valuable for continued analysis. For precipitation in the more recent decades, the Global Precipitation Climatology Project (GPCP; Adler et al. 2003) and similar products exist. These have, however, limitations in the Baltic Sea region.

\section{CONCLUSIONS}

Variations and trends of atmospheric parameters in the Baltic Sea region during the last 200 yr can be summarized as follows. (1) Atmospheric circulation: northward shift of storm tracks and increased cyclonic activity in recent decades, with increased persistence of weather types. (2) Wind: no long-term trend in annual wind statistics since the 19th century, but considerable variations on a (multi-)decadal timescale. Nevertheless, an anthropogenic influence cannot be excluded since the middle of the 20th century. The trend pattern in wind and wave heights over the Northern Hemisphere with a NEshift of storm tracks appears to be consistent with combined natural and external forcing (Wang et al. 2009b). (3) Temperature: continued warming, particularly during spring, and stronger over northern regions (polar amplification). Bhend \& von Storch (2009) detected that the significant warming trends over the Baltic Sea region are consistent with future climate projections under increased greenhouse gas concentrations. (4) Precipitation: no long term trend, but an indication for an increased length of precipitation periods and possibly an increased risk of extreme precipitation events. No clear link to anthropogenic climate change visible for precipitation (Bhend \& von Storch 2008). 
Acknowledgements. The authors acknowledge $\mathrm{H}$. von Storch and A. Omstedt for initiating the BACC projects, and M. Reckermann for administrating the work. L. Bärring, A. Briede, B. Claremar, I. Hanssen-Bauer, J. Holopainen, A. Moberg, O. Nordli, E. Rimkus and J. Wibig are acknowledged for valuable input. C. Zdanowicz is thanked for assistance with ice data.

\section{LITERATURE CITED}

Achberger C, Box JE, Chen D (2007) Nordic region. In: Arguez A (ed) State of the climate in 2006. Bull Am Meteorol Soc 88:S104-S106

Adler RF, Huffman GJ, Chang A, Ferraro R and others (2003) The version-2 Global Precipitation Climatology Project (GPCP) monthly precipitation analysis (1979present). J Hydrometeorol 4:1147-1167

Alexandersson H, Tuomenvirta H, Schmith T, Iden K (2000) Trends of storms in NW Europe derived from an updated pressure data set. Clim Res 14:71-73

Avotniece Z, Rodinov V, Lizuma L, Briede A, Kļaviņš M (2010) Trends in the frequency of extreme climate events in Latvia. Baltica 23:135-148

BACC Author Team (BALTEX Assessment of Climate Change for the Baltic Sea basin) (2008) Assessment of climate change for the Baltic Sea basin. Springer-Verlag, Berlin

BACC Author Team (2014) Second assessment of climate change for the Baltic Sea basin. Springer-Verlag, Berlin

- Barnes EA, Slingo J, Woollings T (2012) A methodology for the comparison of blocking climatologies across indices, models and climate scenarios. Clim Dyn 38:2467-2481

Barnes EA, Dunn-Sigouin E, Masato G, Woollings T (2014) Exploring recent trends in Northern Hemisphere blocking. Geophys Res Lett 41:638-644

Bärring L, Fortuniak K (2009) Multi-indices analysis of southern Scandinavian storminess 1780-2005 and links to interdecadal variations in the NW Europe-North Sea region. Int J Climatol 29:373-384

- Benestad RE, Hanssen-Bauer I, Førland EJ (2007) An evaluation of statistical models for downscaling precipitation and their ability to capture long-term trends. Int $\mathrm{J}$ Climatol 27:649-665

Bhend J, von Storch H (2008) Consistency of observed winter precipitation trends in northern Europe with regional climate change projections. Clim Dyn 31:17-28

Bhend J, von Storch H (2009) Is greenhouse gas forcing a plausible explanation for the observed warming in the Baltic Sea catchment area? Boreal Env Res 14:81-88

Briede A, Lizuma L (2007) Long-term variability of precipitation in the territory of Latvia. In: Kļavinsš M (ed) Climate change in Latvia. p 35-44

Brohan P, Kennedy JJ, Harris I, Tett SFB, Jones PD (2006) Uncertainty estimates in regional and global observed temperature changes: a new dataset from 1850. J Geophys Res 111:D12106, doi:10.1029/2005JD006548

Casty C, Raible CC, Stocker TF, Wanner H, Luterbacher J (2007) A European pattern climatology 1766-2000. Clim Dyn 29:791-805,

> Compo GP, Whitaker JS, Sardeshmukh PD, Matsui M and others (2011) The Twentieth Century Reanalysis Project. QJR Meteorol Soc 137:1-28

> Dangendorf S, Müller-Navarra S, Jensen J, Schenk F, Wahl T, Weisse R (2014) North Sea storminess from a novel storm surge record since AD 1843. J Clim 27:3582-3595

Donat M, Renggli D, Wild S, Alexander L, Leckebusch G, Ulbrich U (2011) Reanalysis suggests long-term upward trends in European storminess since 1871. Geophys Res Lett 38:L14703, doi:10.1029/2011GL047995

Dunn-Sigouin E, Son SW, Lin H (2013) Evaluation of Northern Hemisphere blocking climatology in the Global Environment Multiscale (GEM) model. Mon Weather Rev 141:707-727

> Feser F, Barcikowska M, Krueger O, Schenk F, Weisse R, Xia L (2014) Storminess over the North Atlantic and northwestern Europe: a review. QJR Meteorol Soc doi: 10.1002/qj.2364

> Fink AH, Brücher T, Ermert V, Krüger A, Pinto JG (2009) The European storm Kyrill in January 2007: synoptic evolution, meteorological impacts and some considerations with respect to climate change. Nat Hazards Earth Syst Sci 9:405-423

Fischer-Bruns I, von Storch H, González-Rouco JF, Zorita E (2005) Modelling the variability of midlatitude storm activity on decadal to century time scales. Clim Dyn 25: 461-476

> Francis JA, Vavrus SJ (2012) Evidence linking Arctic amplification to extreme weather in mid-latitudes. Geophys Res Lett 39:L06801, doi:10.1029/2012GL051000

Gulev SK, Latif M, Keenlyside N, Park W, Koltermann KP (2013) North Atlantic Ocean control on surface heat flux on multidecadal timescales. Nature 499:464-467

Gustafsson BG, Schenk F, Blenckner T, Eilola K and others (2012) Reconstructing the development of Baltic Sea eutrophication 1850-2006. Ambio 41:534-548

Hanssen-Bauer I, Drange H, Hisdal IH, Førland EJ and others (2009) Climate in Norway 2100. Norsk klimasenter (in Norwegian)

Hazeleger W, Wang X, Severijns C, Ştefănescu S and others (2012) EC-Earth V2.2: description and validation of a new seamless Earth system prediction model. Clim Dyn 39:2611-2629

Hurrell JW (1995) Decadal trends in the North Atlantic Oscillation: regional temperatures and precipitation. Science 269:676-679

Hurrell JW, Deser C (2009) North Atlantic climate variability: the role of the North Atlantic Oscillation. J Mar Syst 78:28-41

Hurrell JW, Kushnir Y, Ottersen G, Visbeck M (2003) An overview of the North Atlantic Oscillation. The North Atlantic Oscillation: climatic significance and environmental impact. Geophys Monogr 134:1-36

IPCC (Intergovernmental Panel on Climate Change) (2007) The physical science basis. In: Solomon S, Qin D, Manning M, Chen Z and others (eds) Contribution of Working Group I to the Fourth Assessment Report of the Intergovernmental Panel on Climate Change. Cambridge University Press, Cambridge

Jaagus J, Briede A, Rimkus E, Remm K (2010) Precipitation pattern in the Baltic countries under the influence of large-scale atmospheric circulation and local landscape factors. Int J Climatol 30:705-720

Jaagus J, Briede A, Rimkus E, Remm K (2013) Spatial variability and trends in daily minimum and maximum temperatures and in the diurnal temperature range in Lithuania, Latvia and Estonia. Theor Appl Climatol doi: 10.1007/s00704-013-1041-7

Jones PD, Jónsson T, Wheeler D (1997) Extension to the North Atlantic Oscillation using early instrumental pres- 
sure observations from Gibraltar and south-west Iceland. Int J Climatol 17:1433-1450

Kaszewski BM, Filipiuk E (2003) Variability of atmospheric circulation in Central Europe in the summer season 18811998 (on the basis of the Hess-Brezowski classification). Meteorol Z 12:123-130

Kont A, Jaagus J, Orviku K, Palginõmm V and others (2011) Natural development and human activities on Saaremaa Island (Estonia) in the context of climate change and integrated coastal zone management. In: Schernewski G, Hofstede J, Neumann T (eds) Global change and Baltic coastal zones. Springer, Dordrecht, p 117-134

Kriauciuniene J, Meilutyte-Barauskiene D, Reihan A, Koltsova T, Lizuma L, Sarauskiene D (2012) Variability in temperature, precipitation and river discharge in the Baltic States. Boreal Env Res 17:150-162

Krueger O, von Storch H (2011) Evaluation of an air pressure based proxy for storm activity. J Clim 24:2612-2619

Krueger O, Schenk F, Feser F, Weisse R (2013) Inconsistencies between long-term trends in storminess derived from the 20CR reanalysis and observations. J Clim 26: 868-874

Kull A, Kull A, Jaagus J, Kuusemets V, Mander Ü (2008) The effects of fluctuating climatic and weather events on nutrient dynamics in a narrow mosaic riparian peatland. Boreal Env Res 13:243-263

Kushnir Y, Robinson WA, Bladé I, Hall NMJ, Peng S, Sutton R (2002) Atmospheric GCM response to extratropical SST anomalies: synthesis and evaluation. J Clim 15: 2233-2256

Kyselý J (2000) Changes in the occurrence of extreme temperature events. PhD thesis, Charles University, Prague (in Czech with English Abstract)

Kyselý J (2002) Temporal fluctuations in heat waves at PragueKlementinum, the Czech Republic, from 1901-1997, and their relationships to atmospheric circulation. Int $\mathrm{J}$ Climatol 22:33-50

Kyselý J (2010) Recent severe heat waves in central Europe: How to view them in long-term prospect? Int J Climatol 30:89-109

Kyselý J, Huth R (2006) Changes in atmospheric circulation over Europe detected by objective and subjective methods. Theor Appl Climatol 85:19-36

Lehmann A, Getzlaff K, Harlaß J (2011) Detailed assessment of climate variability in the Baltic Sea area for the period 1958 to 2009. Clim Res 46:185-196

Liu J, Curry J, Wang H, Song M, Horton RM (2012) Impact of declining Arctic sea ice on winter snowfall. Proc Natl Acad Sci USA 109:4074-4079

Lizuma L, Kļaviņš M, Briede A, Rodinovs V (2007) Longterm changes of air temperature in Latvia. In: Kļavinsš M (ed) Climate change in Latvia. University of Latvia, Riga p 11-20

Łupikasza E (2010) Spatial and temporal variability of extreme precipitation in Poland in the period 1951-2006. Int J Climatol 30:991-1007

Masato G, Hoskins BJ, Woollings TJ (2013) Winter and summer Northern Hemisphere blocking in CMIP5 models. J Clim 26:7044-7059

Matulla C, Schoener W, Alexandersson H, von Storch H, Wang XL (2008) European storminess: late 19th century to present. Clim Dyn 31:125-130

Meier M, Rutgersson A, Reckerman M (2014) An earth system science program for the Baltic Sea region. Eos Trans AGU 95:109-110
Moberg A, Jones PD (2005) Trends in indices for extremes in daily temperature and precipitation in central Europe. Int J Climatol 25:1149-1171

Moberg A, Tuomenvirta H, Nordli Ø (2005) Recent climatic trends. In: Seppälä M (ed) The physical geography of Fennoscandia. Oxford University Press, Oxford, p 113-133

> Moore GWK, Renfrew IA (2011) Cold European winters: interplay between the NAO and the East Atlantic mode. Atmos Sci Lett 13:1-8

> Overland JE, Wang M (2010) Large-scale atmospheric circulation changes are associated with the recent loss of Arctic sea ice. Tellus A 62:1-9

$>$ Petoukhov V, Semenov VA (2010) A link between reduced Barents-Kara sea ice and cold winter extremes over northern continents. J Geophys Res 115:D21111, doi: 10.1029/2009JD013568

> Rimbu N, Lohmann G (2011) Winter and summer blocking variability in the North Atlantic region: evidence from long-term observational and proxy data from southwestern Greenland. Clim Past 7:543-555

Rimkus E, Kažys J, Bukantis A, Krotovas A (2011) Temporal variation of extreme precipitation events in Lithuania. Oceanologia 53:259-277

Rodwell MJ, Rowell DP, Folland CK (1999) Oceanic forcing of the wintertime North Atlantic Oscillation and European climate. Nature 398:320-323

Russak V (2009) Changes in solar radiation and their influence on temperature trend in Estonia (1955-2007). J Geophys Res 114:D00D01. doi:10.1029/2008JD010613

Scaife AA, Folland CK, Alexander LV, Moberg A, Knight JR (2008) European climate extremes and the North Atlantic Oscillation. J Clim 21:72-83

Schenk F, Zorita E (2012) Reconstruction of high resolution atmospheric fields for Northern Europe using analogupscaling. Clim Past 8:1681-1703

Schmidt H, von Storch H (1993) German Bight storms analyzed. Nature 365:791

Schweiger A, Lindsay R, Zhang J, Steele M, Stern H, Kwok R (2011) Uncertainty in modeled Arctic sea ice volume. J Geophys Res 116:C00D06, doi:10.1029/2011JC007084

Semenov VA, Latif M, Dommenget D, Keenlyside NS, Strehz A, Martin T, Park W (2010) The impact of North Atlantic-Arctic multidecadal variability on Northern Hemisphere surface air temperature. J Clim 23: 5668-5677

> Slonosky VC, Jones PD, Davies TD (2000) Variability of the surface atmospheric circulation over Europe, 1774-1995. Int J Climatol 20:1875-1897

Slonosky VC, Jones PD, Davies TD (2001) Atmospheric circulation and surface temperature in Europe from the 18th century to 1995. Int J Climatol 21:63-75

Sutton RT, Hodson D (2005) Climate Atlantic Ocean forcing of North American and European summer. Science 309: $115-118$

Tammets T, Jaagus J (2013) Climatology of precipitation extremes in Estonia using the method of moving precipitation totals. Theor Appl Climatol 111:623-639

Tang Q, Zhang X, Yang X, Francis JA (2013) Cold winter extremes in northern continents linked to Arctic sea ice loss. Environ Res Lett 8:014036, doi:10.1088/1748-9326/ 8/1/014036

> Tietäväinen H, Tuomenvirta H, Venäläinen A (2010) Annual and seasonal mean temperature in Finland during the last 160 years based on gridded temperature data. Int J Climatol 30:2247-2256 
Ulbrich U, Leckebusch GC, Pinto JG (2009) Extra-tropical cyclones in the present and future climate: a review. Theor Appl Climatol 96:117-131

Vinje T (1998) On the variation during the past 400 years of the Barents Sea ice edge position and Northern Hemisphere temperatures. Proc WCRP Symp Polar Process Global Clim, Rosario, Orcas Island, WA, p 271-273

Vinje T (2001) Anomalies and trends of sea-ice extent and atmospheric circulation in the Nordic Seas during the period 1864-1998. J Clim 14:255-267

Wallace JM, Gutzler DS (1981) Teleconnnections in the geopotential height field during the Northern Hemisphere winter. Mon Weather Rev 109:784-812

Wang XL, Zwiers FW, Swail VR, Feng Y (2009a) Trends and variability of storminess in the Northeast Atlantic region, 1874-2007. Clim Dyn 33:1179-1195

> Wang XL, Swail VR, Zwiers FW, Zhang X, Feng Y (2009b) Detection of external influence on trends of atmospheric storminess and northern oceans wave heights. Clim Dyn 32:189-203

Wang XL, Wan H, Zwiers FW, Swail VR and others (2011) Trends and low-frequency variability of storminess over western Europe, 1878-2007. Clim Dyn 37:2355-2371

The WASA Group (1998) Changing waves and storms in the Northeast Atlantic? Bull Am Meteorol Soc 79:741-760

Werner PC, Gerstengarbe FW, Fraedrich K, Oesterle H (2000) Recent climate change in the North Atlantic/European sector. Int J Climatol 20:463-471

Wibig J (2008) Variability of weather extremes in Poland in the period 1951-2006. In: Sigro Rodriguez J, Brunet

Editorial responsibility: Oliver Frauenfeld, College Station, Texas, USA
India M, Aguilar Anfrons E (eds) Cambio climático regional y sus impactos. Publ Asociación Española de Climatología A6:469-479

Wibig J (2009) Variability of daily precipitation totals in Poland (1951-2000). Geogr Pol 82:21-32

Woollings T, Hoskins BJ, Blackburn ML, Berrisford P (2008) A new Rossby wave-breaking interpretation of the North Atlantic Oscillation. J Atmos Sci 65:609-625

Xia L, von Storch H, Feser F (2013) Quasi-stationarity of centennial Northern Hemisphere mid-latitude winter storm tracks. Clim Dyn 41:901-916

Yang S, Christensen JH, Stendel M, Hansen AH (2011) Arctic sea ice reduction and the extreme cold winters in Europe revisited. Poster TH102A, WCRP Conf, Denver, CO, October 24-28, 2011

Ylhäisi JS, Tietäväinen H, Peltonen-Sainio P, Venäläinen A, Eklund J, Räisänen J, Jylhä K (2010) Growing season precipitation in Finland under recent and projected climate. Nat Hazards Earth Syst Sci 10:1563-1574

> Zolina OG (2011) Changes in the duration of synoptic rainy periods in Europe from 1950 to 2008 and their relation to extreme precipitation. Dokl Earth Sci 436:279-283

> Zolina O, Simmer C, Belyaev K, Kapala A, Gulev S (2009) Improving estimates of heavy and extreme precipitation using daily records from European rain gauges. J Hydrometeorol 10:701-716

Zolina O, Simmer C, Gulev S, Kollet S (2010) Changing structure of European precipitation: longer wet periods leading to more abundant rainfalls. Geophys Res Lett 37 : L06704, doi:10.1029/2010GL042468

Submitted: August 26, 2013; Accepted: May 23, 2014

Proofs received from author(s): September 18, 2014 